\title{
Cervical Endometriosis - Case Report and Review of Literature
}

\author{
Raluca Gabriela SUBA', Ion IONUT', Octavian ENCIU2,3, Bogdan MARINESCU1,3
}

\begin{abstract}
Endometriosis became a public health problem both due to the increasing number of affected patients and the severe quality of life impairment. Cervical endometriosis is defined as the presence of endometrial glands and stroma at cervical level. Primary and secondary cervical endometriosis are two separates entities that require distinct management. Symptomatic cases diagnosed with primary cervical endometriosis have indication for ERAD while patients with secondary cervical endometriosis should be referred to a specialized center because the surgical treatment may imply a high degree of difficulty. We present a 24-year-old woman with no history of cervical interventions, first diagnosed with cervical displasia and referred to our center for a second opinion. Secondary cervical endometriosis and vaginal endometriotic nodule were diagnosed. Following the general consensus for the benefits of surgery for endometriosis associated with pelvic pain, the patient was considered a candidate for laparoscopic surgery. Complete resection of the endometriotic tissue including the vaginal nodule with laparoscopic suture of the vaginal wall was realized. Laparoscopic surgery for endometriosis is proven to improve the patients' quality of life, diminishing the symptoms and increases the likelihood of obtaining a spontaneous pregnancy. The presented case illustrates the benefits of surgery for secondary cervical endometriosis with marker improvement in quality of life proven with EHP-30 up to 2 years after surgery.
\end{abstract}

Keywords: primary and secondary cervical endometriosis, vaginal endometriosis, complete laparoscopic resection, quality of life - EHP-30.

\section{Rezumat}

Endometrioza a devenit o problemă de sănătate publică atât prin numărul în creștere de paciente afectate de boală, cât mai ales prin afectarea severă a calității vieții acestor paciente. Endometrioza cervicală este definită ca prezența de insule de glande și stromă de tip endometrial la nivelul cervixului. Endometrioza primară și secundară sunt două entități distincte ce necesită abord terapeutic diferit. Pacientele simptomatice diagnosticate cu endometrioză primară au indicație de ERAD, în timp ce pacientele cu endometrioză secundară trebuie tratate în cadrul unui centru specializat, deoarece intervenția chirurgicală poate avea un grad crescut de dificultate. Pezentăm cazul unei paciente în vârstă de 24 de ani, fără antecedente de intervenții la nivel cervical, diagnosticată inițial cu displazie cervicală, care s-a prezentat în cadrul clinicii pentru o a doua opinie. În urma examinării, a fost stabilit diagnosticul de endometrioză cervicală secundară și nodul de endometrioză vaginală. Urmând consensul general conform căruia chirurgia laparoscopică aduce beneficii pacientelor cu endometrioză ce asociază durere pelvină, pacienta a fost propusă pentru intervenție chirurgicală. Pe cale laparoscopică a fost realizată rezecția completă a țesutului de endometrioză inclusiv a nodului vaginal cu sutura laparoscopică a peretelui vaginal. Chirurgia laparoscopică adresată endometriozei s-a dovedit eficientă în îmbunătățirea calității vieții, diminuarea simptomatologiei și creșterea probabilității de obținere a sarcinii. Cazul prezentat ilustrează beneficiile tratamentului chirurgical pentru endometrioză cervicală secundară cu îmbunătățirea calității vieții cuantificată prin EHP-30 la 2 ani după intervenție.

Cuvinte cheie: endometrioză cervicală primară și secundară, endometrioza vaginală, rezecție laparoscopică completă, calitatea vieții - EHP-30.

\footnotetext{
${ }^{1}$ „Prof. Dr. Panait Sarbu" Clinical Hospital of Obstetrics and Gynecology, Bucharest, Romania

2 "Elias" Emergency University Hospital, Bucharest, Romania

3 "Carol Davila" University of Medicine and Pharmacy, Bucharest, Romania
}

\section{Corresponding author.}

Octavian Enciu, Department of Surgery, Elias Emergency University Hospital, $17^{\text {th }}$ Marasti Boulevard, 011461, Bucharest, Romania.

E-mail: esoctavian@gmail.com 


\section{INTRODUCTION}

Endometriosis became a public health problem both due to the increasing number of affected patients and the severe quality of life impairment. The incidence of the disease has been estimated to $5-10 \%$ of adult women, with a rise in incidence with respect to the previous generations, affecting presently roughly 176 million women throughout the world ${ }^{1}$.

First reported by Fels in 1928, cervical endometriosis it was considered a rare localization of this disease but authors like Williams, Novak and Hoge have overturned this hypothesis, Williams having published a series of 111 cases by $1960^{2,3}$.

For a correct definition of this pathology, primary and secondary endometriosis need to be understood as distinct entities. Secondary endometriosis represents the extension of the disease from the pelvis, usually from the rectovaginal septum, and is more frequent. Primary cervical endometriosis is a rare entity and is defined as ectopic endometrial tissue at the level of the cervix ${ }^{4}$.

Siddal and Mack have established 4 criteria for primary endometriosis: 1-localization of endometrial tissue on the anterior lip of the cervix; 2-presence of endometrial tissue should be limited to the surface of the cervix and should not extend beyond the cervical squamous epithelium; 3-the absence of uterine, rectovaginal septum and vaginal wall endometriosis; 4-cessation of symptoms after removal of cervical endometrial lesions ${ }^{5,6}$.

Cervical procedures (punch biopsy, LEEP, conization) or intrapartum cervical laceration, are considered risk factors for cervical endometriosis. Due to the increased rates of these procedures in the last decades, a rise in incidence of cervical endometriosis should be expected ${ }^{7}$.

Cervical endometriosis symptomatology may include: postcoital bleeding, spotting, menorrhagia, vaginal discharge but patients may also be asymptomatic. In rare cases, the bleeding could be life threatening ${ }^{8}$. If deep endometriosis is present, the clinical picture should resemble typical endometriosis (dysmenorrhea 6-80\%, dyspareunia $40-50 \%$, chronic pelvic $30-50 \%$ pain and infertility $30-40 \%)^{9}$.

The differential diagnosis includes benign cervical lesions as polyps, myoma, endocervical glandular dysplasia, adenocarcinoma in situ and rarely invasive adenocarcinoma. Several cases have been reported where after radical surgery for abnormal PAP smear results, final pathology demonstrated cervical endometriosis ${ }^{10}$.

\section{CASE REPORT}

A 24-year-old Romanian woman was examined for a second opinion in the Gynecology Department of „Professor Panait Sîrbu Hospital”. She was previously examined two months before and diagnosed with glandular cervical dysplasia (PAP smear that demonstrated AGCNOS). Biopsy demonstrated cervical endometriosis so she was referred to a specialized center.

During anamnesis it was noted that patient was nulliparous and suffered dysmenorrhea 7-VAS, chronic pelvic pain 3-VAS, without dyspareunia. The patient was diagnosed with primary infertility. She had no previously surgical intervention and no family history of endometriosis.

On speculum examination 2 violet macular lesions, multiple $5 \mathrm{~mm}$ red-violet polypoid lesions at 6-9 o'clock on the vagina wall and 2 violet macular lesions on the cervix surface were observed (Figure 1).

Bimanual pelvic examination revealed diminished uterine mobility and pain during mobilization, pain during examination of the thickened and retracted retro-cervical space. The posterior vaginal cul-de-sac was shortened.

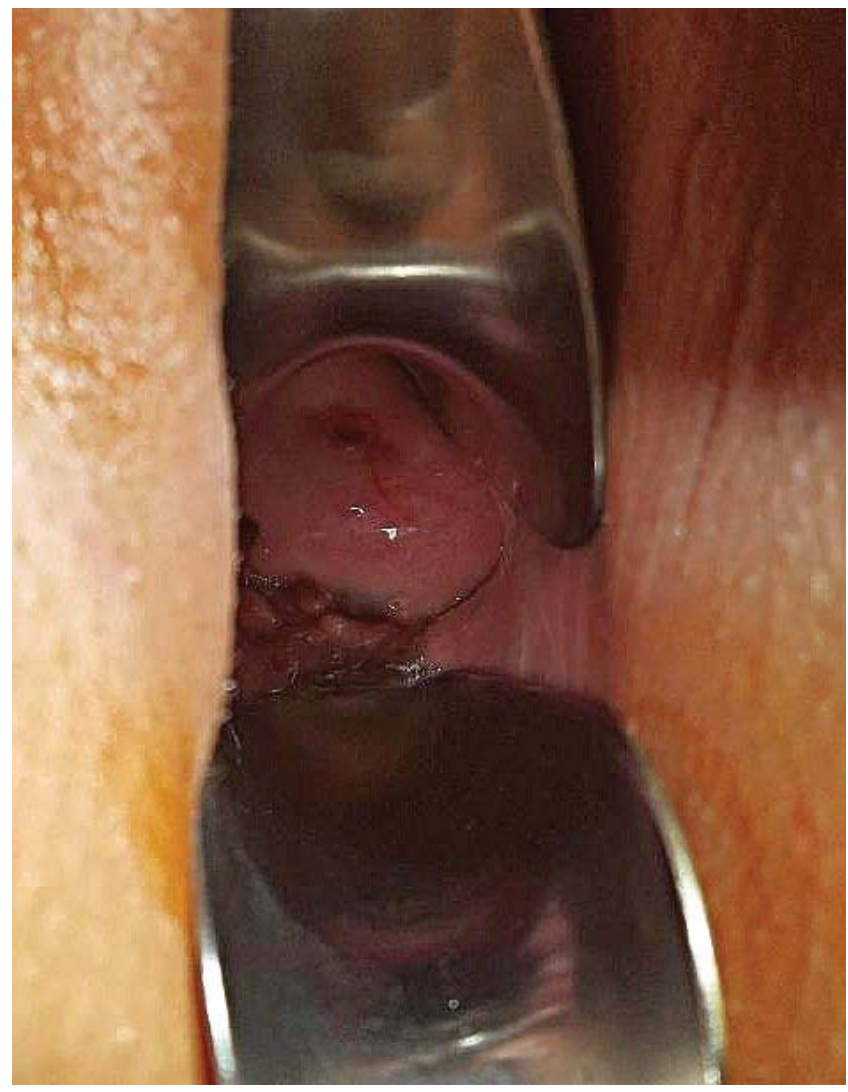

Figure 1. Speculum examination. 
Colposcopy was unrevealing because the squamocolumnar junction was type III. During examination with acetic acid and Lugol no new lesions could be described. Transvaginal ultrasound was normal.

The patient had no digestive symptoms so pelvic MRI was not mandatory, even though pelvic MRI with intrarectal and intravaginal gel could have revealed the extension of the endometriotic lesions.

Following the general consensus for the benefits of surgery for endometriosis associated with pelvic pain, the patient was considered a candidate for laparoscopic surgery $^{11-13}$.

During laparoscopic exploration the uterus and the ovary appeared normal so as did the peritoneum lining the ovarian fossae. The anterior aspect of the rectum was adherent to the uterus above the isthmus (Figure 2).

The dissection began within normal anatomy with the identification and dissection of the ureters in the iliac part and continued at the paracervical level. Then the pararectal spaces were opened with the dissection of the uterosacral ligaments, having exposed the anterior and lateral parts of the rectum. Dissection continued in the space between the rectum and the cervix with the identification and resection of a large endometriosis nodule. Endometriosis typically invades surrounding tissues and an ideal dissection plane most often can't be found to allow en-block resection, in our case the resection left endometriotic tissue both on the anterior aspect of the rectum, the cervix and the vagina. The remaining tissue on the rectum was removed by shaving with monopolar cautery. The tissue remaining on the vagina and cervix was clinically reevaluated by

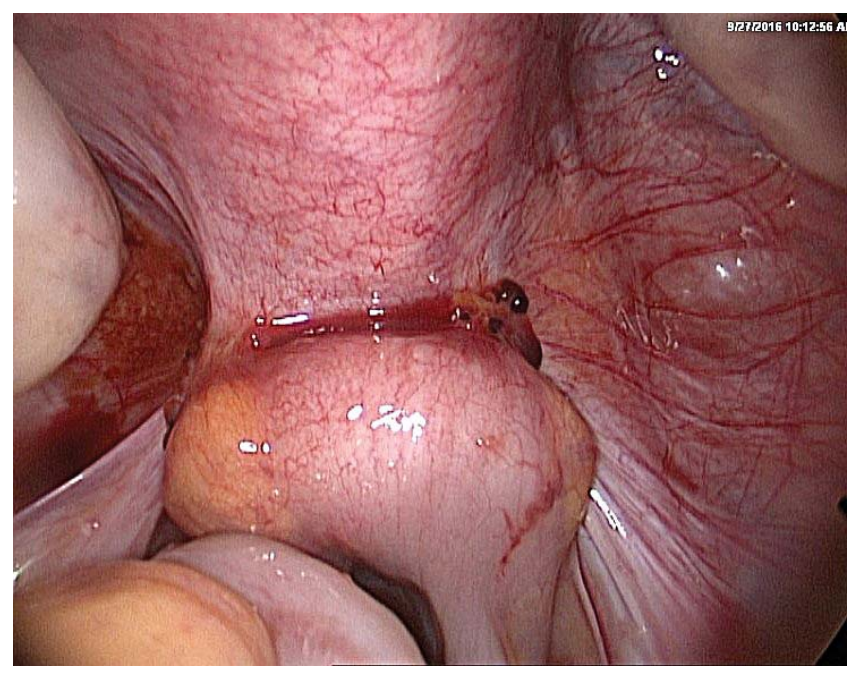

Figure 2. Intraoperative aspect - rectum adherent to the cervix.

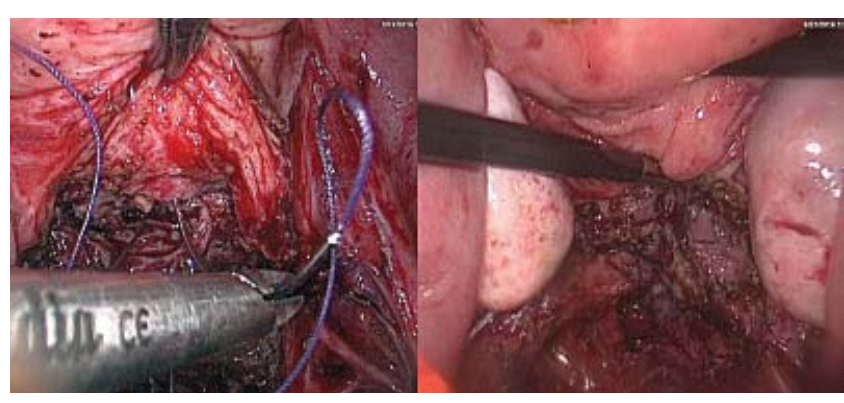

Figure 3. Cervico-vaginal suture.

intraoperative vaginal examination and resection was decided. En-block resection of a $3 / 3 \mathrm{~cm}$ vaginal nodule followed with continuous suture of the vaginal wall and cervical shaving. The cervical canal was tutored with a stent in order to prevent stenosis (Figure 3-4). Bilateral tubal permeability test was positive (Figure 5). Final pathology examination confirmed cervical endometriosis (Figure 6).

The postoperative course was uneventful, the pelvic drainage was removed in the second postoperative day and the cervical stent was removed after 14 days.

The patient completed the EHP-30 questionnaire both before and after the surgery at 6,12 and 24 months ${ }^{14}$. Dysmenorrhea and dyspareunia were certified using the VAS (visual analogue scale) ${ }^{15}$. Preoperative dysmenorrhea scored 7 , dyspareunia 0 and 3 for chronic pelvic pain while during follow up at 2 years dysmenorrhea scored 2 and dyspareunia scored 0 and chronic pelvic pain 1 .

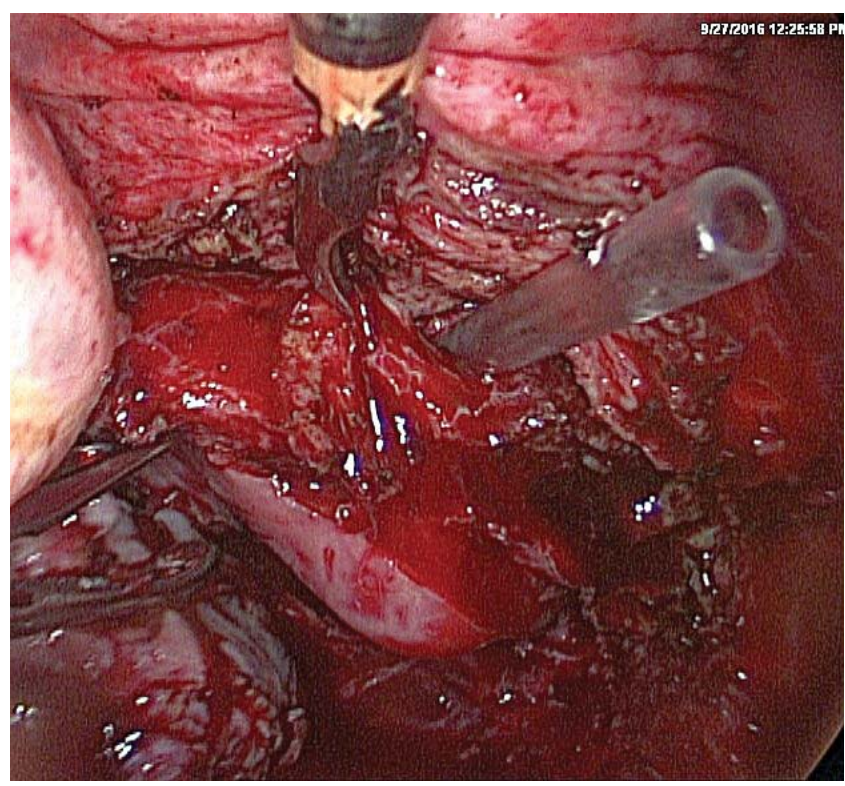

Figure 4. Cervical stent. 


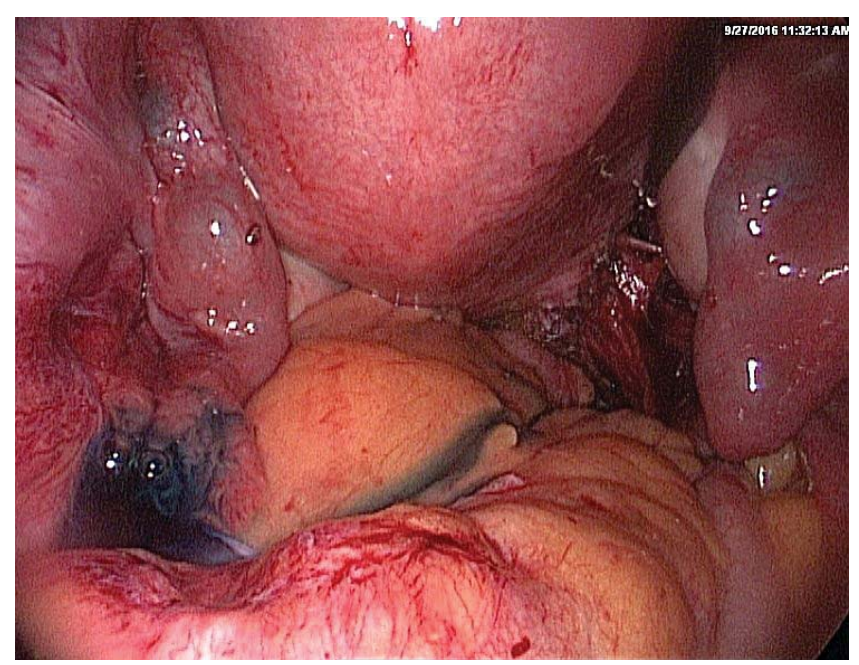

Figure 5. Tubal permeability test.

\section{DISCUSSION}

The peculiarity of the cases resides in the fact that the patient had none of the symptoms most frequently associated with cervical endometriosis and although she had dysmenorrhea, dyspareunia was absent. The endometriotic lesions involved the rectovaginal septum and mobilization of the cervix provoked pain. For the less acquainted physician, the endometriotic lesions on the cervix may represent the sole lesions when in fact these are the tip of the iceberg. In this case, the ERAD approach would have been suboptimal.

The patient does not present none of the risk factors for cervical endometriosis (natural labor with secondary impairment of the cervix, cervical procedures - punch biopsy, ERAD, conization).

Another remarkable aspect of the presented case is that the lesions were limited to the rectovaginal space, cervix and vagina, with no involvement of the ovary and the peritoneum lining in the ovarian fossae. If endometrioma would have been found on ultrasound the diagnosis would have been ready made.

Cervical endometriosis may mimic cervical glandular anomalies with false positive PAP smear results. These results are explained by cytomorphological alterations under hormonal variations during the menstrual cycle ${ }^{16}$.

Patients with asymptomatic primary cervical endometriosis do not require treatment, the wait and see approach being feasible. Symptomatic cases diagnosed with primary cervical endometriosis have indication for ERAD. Local destructive techniques like diathermy have high recurrence rates ${ }^{17}$. Cryotherapy and laser therapy have insufficient data reported.

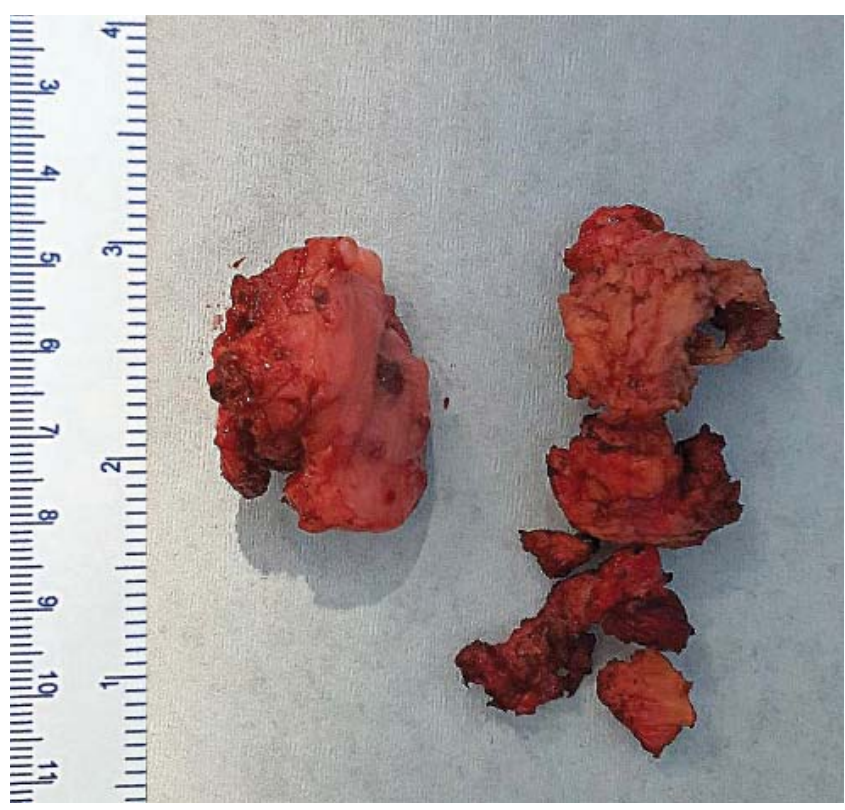

Figure 6. Resection specimen.

Patients with secondary cervical endometriosis should be referred to a specialized center because the surgical treatment may imply a high degree of difficulty. Extensive endometriosis with colorectal involvement may require a multidisciplinary team including a digestive surgeon ${ }^{18}$.

\section{CONCLUSION}

The differential diagnosis between primary and secondary cervical endometriosis is very important because the therapeutic management is different. The main concern is the undertreatment of secondary endometriosis, only prolonging these patients' angst.

Laparoscopic surgery for endometriosis is proven to improve the patients' quality of life, diminishing the symptoms and increases the likelihood of obtaining a spontaneous pregnancy.

The presented case illustrates the benefits of surgery for secondary cervical endometriosis with marker improvement in quality of life proven with EHP-30 up to 2 years after surgery.

\section{Compliance with ethics requirements:}

The authors declare no conflict of interest regarding this article.

The authors declare that all the procedures and experiments of this study respect the ethical standards in the Helsinki Declaration of 1975, as revised in 2008(5), as well as the national law. Informed consent was obtained from all the patients included in the study. 


\section{References}

1. Adamson GD, Kennedy SH, Hummelshoj L. Creating solutions in endometriosis: global collaboration through the World Endometriosis Research Foundation. J Endometr 2010;2:3-6.

2. Park, Junsik, et al. „Cervical Endometriosis in a Post-menopausal Woman: A Case Report." The Journal of Korean Society of Menopause 17.3 (2011): 174-177.

3. Williams, George A. «Endometriosis of the cervix uteri-a common disease." American Journal of Obstetrics \& Gynecology80.4 (1960): 734-741.

4. Cramer, Daniel W., and Stacey A. Missmer. «Epidemiology of endometriosis." Endometriosis in Clinical Practice. CRC Press, 2004. 79-94.

5. Siddall, R.S. and Mack, H.C. Primary endometriosis of the cervix uteri. Harper Hosp. Bull. 7:195, 1949

6. Siddall, R. S., and R.W. and Mack, H.C. Primary endometriosis of the vagina; portion of the cervix uteri. Am. J. Obst. And Gynec. 60:765, 1949

7. Gardner $\mathrm{HL}$, Kaufmann $\mathrm{RH}$. Benign diseases of the vulva and vagina. St Louis, Mo: CV Mosby; 1969. pp. 98-104.

8. Yokota, Naho, et al. „A severe vaginal hemorrhage caused by cervical endometriosis." American journal of obstetrics and gynecology 199.1 (2008): e12-e13.

9. Shaw RW. An Atlas of Endometriosis. Carnforth: Parthenon Publishing Group Ltd.; 1993.

10. Lundeen, Sarah J., et al. „Abnormal cervicovaginal smears due to endometriosis: a continuing problem." Diagnostic cytopathology 26.1 (2002): 35-40.
11. Duffy JM, Arambage K, Correa FJ, Olive D, Farquhar C, Garry R, et al. Laparoscopic surgery for endometriosis. Cochrane Database Syst Rev 2014: CD011031.

12. Jacobson TZ, Barlow D, Farquhar C, Koninckx PR, Olive D., Laparoscopic surgery for subfertile associated with endometriosis, Cochrane Database Syst 2012 CD001398

13. Carmona F, Martinez -Zamora MA, Rabanal A, Martinez-Roman S, Balasch J. Ovarian cystectomy versus laser vaporization in the treatment of ovarian endometriomas: a randomized clinical trial with a five -year follow-up Fertil Steril 2011

14. Khong, Su-Yen, Alan Lam, and Georgina Luscombe. "Is the 30item Endometriosis Health Profile (EHP-30) suitable as a selfreport health status instrument for clinical trials?." Fertility and sterility 94.5 (2010): 1928-1932.

15. MPQ, McGill Pain Questionnaire, Chronic Pain Grade Scale, and Bodily Pain Scale. "Measures of adult pain." Arthritis Care \& Research 63.S11 (2011): S240-S252.

16. Hanau, Cheryl A., Norma Begley, and Marluce Bibbo. «Cervical endometriosis: a potential pitfall in the evaluation of glandular cells in cervical smears." Diagnostic cytopathology 16.3 (1997) 274-280.

17. Shaw RW. An Atlas of Endometriosis. Carnforth: Parthenon Publishing Group Ltd.; 1993.

18. Roman, H., Rozsnayi, F., Puscasiu, L., Resch, B., Belhiba, H., Lefebure, B., ... \& Tuech, J. J. (2010). Complications associated with two laparoscopic procedures used in the management of rectal endometriosis. JSLS: Journal of the Society of Laparoendoscopic Surgeons, 14(2), 169. 
